\title{
ŹRÓDŁA PRZEWAGI KONKURENCYJNEJ PRZEDSIĘBIORSTWA - AKTUALNY STAN DYSKUSJI
}

\section{Wstęp}

Trwała przewaga konkurencyjna stanowi kluczową kategorię w rozważaniach z zakresu teorii ekonomii (zwłaszcza mikroekonomii) i zarządzania strategicznego, dotyczących nie tylko konkurencji i sposobów konkurowania, ale także funkcjonowania, przetrwania i rozwoju przedsiębiorstwa. Jak zauważył M.E. Porter, „,przewaga konkurencyjna stanowi sedno działalności przedsiębiorstwa na konkurencyjnym rynku"1 i jest faktycznym kreatorem wyników firmy na konkurencyjnych rynkach ${ }^{2}$. Jest ona zarazem umiejętnością wykorzystania potencjału konkurencyjności, którym dysponują przedsiębiorstwa. Umiejętność ta przejawia się $\mathrm{w}$ trafnym wyborze ścieżki budowania i umacniania tego potencjału oraz w efektywnym stosowaniu instrumentów konkurowania.

W rezultacie uzyskania przewagi konkurencyjnej przedsiębiorstwo osiąga ponadprzeciętne zyski i zajmuje mocną pozycję konkurencyjną, lepiej niż konkurencja bowiem wykorzystuje określone zasoby i umiejętności oraz lepiej - w porównaniu z rywalami - dostosowuje te umiejętności do kluczowych czynników sukcesu w danym sektorze ${ }^{3}$.

Zgodność poglądów odnośnie do zasadniczego znaczenia przewagi konkurencyjnej dla funkcjonowania i rozwoju współczesnych przedsiębiorstw nie doprowadziła jednak do jednoznacznego jej zdefiniowania i rozumienia. Problematyka przewagi konkurencyjnej nadal wzbudza wiele kontrowersji ${ }^{4}$. W literaturze przedstawia się wiele koncepcji przewagi konkurencyjnej przedsiębiorstwa i wciąż powstają nowe. Wynika to prawdopodobnie ze złożoności jej charakteru, różnorodności jej źródeł oraz odmienności rodzajów podejścia do jej identyfikowania i wymiarowania ${ }^{5}$.

\footnotetext{
* Asystent, Katedra Zarządzania Przedsiębiorstwem, Wydział Zarządzania, UŁ.

${ }^{1}$ M.E. Porter, Przewaga konkurencyjna. Osiaganie i utrzymywanie lepszych wyników, Helion, Gliwice 2006, s. 17 (wydanie oryginalne: M.E. Porter, Competitive Adventage: Creating and Sustaining Superior Performance, Free Press, New York 1985).

${ }^{2}$ Ibidem, s. 23.

${ }^{3}$ D. Faulkner, C. Bowman, Strategie konkurencji, Gebethner i Ska, Warszawa 1996, s. 29.

${ }^{4} \mathrm{~J}$. Macias, Nowe koncepcje przewagi konkurencyjnej wspótczesnych przedsiębiorstw, „Przegląd Organizacji” 2008, nr 9, s. 11.

${ }^{5}$ M.J. Stankiewicz, Konkurencyjność przedsiębiorstwa. Budowanie konkurencyjności przedsiębiorstwa w warunkach globalizacji, TNOiK Dom Organizatora, Torun 2002, s. 166.
} 
Analizując problemy konstruowania definicji przewagi konkurencyjnej (czy szerzej tworzenia modeli konkurencji), można dostrzec, że wiele zagadnień pozostaje nadal poza obszarem zainteresowań badaczy ${ }^{6}$. Są to przede wszystkim kwestie dotyczące przyjmowanych postaw badawczych, założeń wprowadzanych podczas definiowania przewag konkurencyjnych, deklarowanych celów budowania definicji, zakresu stosowanych uproszczeń i redukcji cech badanej rzeczywistości, języka i narzędzi wykorzystywanych do opisu zjawiska, wreszcie zdolności do przedstawienia $w$ ramach stworzonej definicji dynamiki i interaktywnego charakteru elementów konstytuujących to pojęcie. Wydaje się, że niektórym autorom chodziło raczej o szybkie uzyskanie odpowiedzi na postawione $\mathrm{w}$ warunkach ceteris paribus pytanie niż o spójne wyjaśnienie mechanizmów kreowania przewagi na konkurencyjnym rynku.

Od lat 80. ubiegłego wieku toczy się ożywiona debata, której przedmiotem jest względna trwałość przewagi konkurencyjnej. Chociaż w literaturze można znaleźć przeciwstawne argumenty na ten temat, to jednak dominuje pogląd, że przewaga konkurencyjna nie ma charakteru absolutnego; nie tylko nie jest dana przedsiębiorstwu raz na zawsze, ale nawet na dłuższy czas ${ }^{7}$. W warunkach tzw. zmiany obejmującej (encompassing change) ${ }^{8}$ oraz radykalnego oddziaływania konkurentów (hiperkonkurencji) ${ }^{9}$, z jakimi mamy do czynienia, możliwe jest

\footnotetext{
${ }^{6}$ W. Świtalski, Innowacje i konkurencyjność, Wydawnictwo UW, Warszawa 2005, s. 161.

${ }^{7}$ Zob. np. P. Kotler, A. Gestern, Jak wygrywać w warunkach hiperkonkurencji, „Rzeczpospolita” 2001, nr 74, dodatek: „Moja kariera”, s. D3; R.W. Wiggins, T.W. Ruefli, Schumpeter's ghost: Is hypercompetition making the best of times shorter, „Strategic Management Journal” 2005, vol. 26, no. 10, s. 887-911. Przywołani autorzy uważają, że brakuje dowodów potwierdzających istnienie trwałej przewagi konkurencyjnej. Niektórzy badacze, krytykując koncepcję hiperkonkurencji, koncentrują się jednak na poszukiwaniu źródeł trwałej przewagi konkurencyjnej i identyfikowaniu czynników mających dominujące znaczenie w jej utrwalaniu, twierdząc, że są dowody na występowanie trwałej przewagi konkurencyjnej. Zob. np. R. Makadok, Can firstmover and early-mover advantages be sustained in an industry with low barriers to entry/imitation, „Strategic Management Journal” 1998, vol. 19, no. 7, s. 683-696; G. McNamara, P.M. Vaaler, C. Devers, Same as it ever was: the search for evidence of increasing hypercompetition, ibidem, 2003, vol. 24, no. 3, s. 261-278.

${ }^{8}$ Przez zmianę obejmującą rozumie się radykalne innowacje, które obejmują jednocześnie głębokie zmiany technologiczne, jak i znaczne zmiany umiejętności w zakresie kreowania produktów i usług oraz ich sprzedaży na rynku. Charakteryzuje je zatem nowość technologiczna oraz nowość rynkowa. Zob. E. Cyrson, Nowy paradygmat strategii konkurencji, [w:] E. Skawińska (red.), Konkurencyjność przedsiębiorstw - nowe podejście, Wydawnictwo Naukowe PWN, Warszawa-Poznań, 2002, s. 39.

${ }^{9}$ Pojęcie hiperkonkurencji jest określane jako proces intensywnej rywalizacji między producentami i dostawcami w warunkach przybierającego na sile dążenia do przetrwania i zmieniających się zakresów działań rynkowych. Wymiary hiperkonkurencji opisuje się w takich kategoriach, jak: jakość, koszty, terminowość realizacji zadań, twierdze (tj. kombinacja produktu i rynku, na których producent ma okresową przewagę), dobór najlepszego momentu do podjęcia określonych przedsięwzięć wewnątrz przedsiębiorstwa i na rynku, obrona
} 
osiąganie jedynie chwilowej przewagi konkurencyjnej. Podstawowym celem strategii przedsiębiorstwa staje się nie budowanie i obrona trwałej przewagi konkurencyjnej, lecz raczej jej kreowanie w kolejnych okresach ${ }^{10}$. Możliwości budowania sekwencji krótkookresowej przewagi konkurencyjnej są determinowane charakterem i liczbą odrębnych jej źródeł, a także ciągłym dążeniem przedsiębiorstwa do stałego podnoszenia jej poziomu ${ }^{11}$.

Celem niniejszego opracowania jest omówienie na podstawie literatury przedmiotu najważniejszych wątków w dyskusji o źródłach kreowania przewagi konkurencyjnej współczesnego przedsiębiorstwa oraz wskazanie tych źródeł, które przesądzają o jego zdolności do rozwijania zbioru przewag okresowych. Odwołując się do teorii przewagi komparatywnej (comparative advantage theory), zwanej także teorią przewagi zasobowej (resource-advantage theory), sformułowanej przez S.D. Hunta i R.M. Morgana, opisano mechanizm osiągania przewagi konkurencyjnej z uwzględnieniem następujących po sobie działań przedsiębiorstwa.

\section{Tradycyjne poglądy na źródła przewagi konkurencyjnej przedsiębiorstwa}

W literaturze przedmiotu występuje duża różnorodność poglądów odnośnie do źródeł przewagi konkurencyjnej. Wynika to m.in. z funkcjonowania jednocześnie wielu koncepcji konkurencyjności przedsiębiorstwa i przyjmowania określonych metod badawczych ${ }^{12}$, ale przede wszystkim z różnego postrzegania

własnych twierdz i ataków na twierdze rywali, a także zapewnienie uczestnikom rywalizacji źródeł finansowania na dogodnych warunkach oraz wiedzy i kompetencji w firmach. W tym relatywnie nowym podejściu do rywalizacji rynkowej podnosi się kwestie szybkości zachodzących w otoczeniu firmy zmian oraz potrzebę nadążania za nimi w praktykach menedżerskich. Wydaje się ono próbą operacjonalizacji ujęć konkurencji zaproponowanych jeszcze w latach 80 . ubiegłego wieku przez M.E. Portera. Zob. np. A.E. Singer, Hypercompetition, Business PressThomson Learning London 2000, s. 64-65.

${ }^{10}$ J. Polowczyk, Zarządzanie strategiczne $w$ przedsiębiorstwie $w$ ujęciu behawioralnym, Wydawnictwo UE w Poznaniu, Poznań 2012, s. 122.

${ }^{11}$ E. Brzozowska, Przewaga konkurencyjna elementem konkurencyjności przedsiębiorstw, [w:] J. Szabłowski (red.), Strategie konkurencji przedsiębiorstw - wybrane zagadnienia, Wydawnictwo Wyższej Szkoły Finansów i Zarządzania w Białymstoku, Białystok 2004, s. 203.

${ }^{12} \mathrm{O}$ wielowymiarowym rozumieniu konkurencyjności przedsiębiorstw, także w kontekście międzynarodowym, zob. m.in. w: M. Haffer, Ogólna charakterystyka wspótczesnej konkurencji międzynarodowej, [w:] M.J. Stankiewicz (red.), Zarzqdzanie wiedza jako kluczowy czynnik międzynarodowej konkurencyjności przedsiębiorstwa, TNOiK Dom Organizatora, Toruń 2006, s. 31-61; Z. Pierścionek, Wspótczesne koncepcje konkurencyjności przedsiębiorstwa, [w:] Z. Pierścionek, S. Jurek-Stępień (red.), Czynniki sukcesu polskich przedsiębiorstw na rynkach Unii Europejskiej, Szkoła Główna Handlowa w Warszawie - Oficyna Wydawnicza, Warszawa 2006, 
samej przewagi konkurencyjnej oraz głębokości i uniwersalności ujmowania jej źródeł przez reprezentantów różnych nurtów badań nad tą tematyką ${ }^{13}$. Ponadto ogólnoświatowy charakter konkurencji i tworzenie się rynków globalnych, będące następstwem procesów globalizacji, stwarzają nowe możliwości podejmowania działań konkurencyjnych przez przedsiębiorstwa oraz różnicują znaczenie poszczególnych źródeł ich przewagi konkurencyjnej ${ }^{14}$.

Poszukując źródeł przewagi konkurencyjnej przedsiębiorstwa, można odwołać się zarówno do tradycyjnych, jak i nowszych koncepcji konkurencyjności ${ }^{15}$. Autorzy tradycyjnych koncepcji konkurencyjności przedsiębiorstwa koncentrują się na realnych mechanizmach i czynnikach konkurencyjności, takich jak koszty, jakość, marketing, logistyka, pozycja na rynku, oraz na bezpośrednich źródłach rynkowej przewagi konkurencyjnej, takich jak specjalizacja, doświadczenie, dostęp do zasobów surowcowych, przywództwo kosztowe, systemy zarządzania jakością czy strategie marketingowe. Najważniejsze $\mathrm{z}$ nich to ${ }^{16}$ :

- koncepcja konkurencyjności kosztowej, oparta na efektach skali produkcji, specjalizacji, standaryzacji oraz efektach doświadczenia;

- przywództwo jakościowe oraz systemy zarządzania jakością;

- konkurowanie oparte na sile rynkowej przedsiębiorstwa (pozycja lidera rynkowej oraz firmy dominującej na rynku);

- marketingowa koncepcja konkurencyjności;

- przywództwo kosztowe oraz wyróżnianie się.

W tradycyjnych koncepcjach konkurencyjności zakłada się występowanie konkurencji oligopolistycznej oraz monopolistycznej, a także niechęć przedsiębiorstw do współpracy i przyjmowanie przez nie postawy konfrontacyjnej. Ponadto mają one możliwość osiągnięcia stabilnej długookresowej przewagi konkurencyjnej.

s. 15-46; E. Urbanowska-Sojkin, Niematerialne czynniki konkurencyjności przedsiębiorstwa, [w:] E. Urbanowska-Sojkin, P. Banaszyk (red.), Współczesne metody zarządzania strategicznego przedsiębiorstwem, Wydawnictwo AE w Poznaniu, Poznań 2004, s. 44-49.

${ }^{13}$ Różnice między poszczególnymi ujęciami przewagi konkurencyjnej można rozpatrywać $\mathrm{w}$ różnych aspektach, a mianowicie strukturalnym, kontekstu analizy, konkurencyjnym (punktu odniesienia), wynikowym i czasowym. Często podkreśla się, że każda przewaga konkurencyjna jest identyfikowana na podstawie warunków obowiązujących w określonym czasie z uwzględnieniem określonych związków przyczynowo-skutkowych. Zob. szerzej M. Małkowska, Metody kwantyfikacji przewagi konkurencyjnej przedsiębiorstwa, [w:] E. Urbanowska-Sojkin, P. Banaszyk (red.), Współczesne metody zarządzania..., s. 67.

${ }^{14}$ Szerzej na temat źródeł przewagi konkurencyjnej w kontekście międzynarodowej konkurencyjności firm zob. Z. Pierścionek, Klasyfikacja źródet przewagi konkurencyjnej, [w:] K. Poznańska, A. Sosnowska (red.), Źródła przewagi konkurencyjnej przedsiębiorstw, Szkoła Główna Handlowa, Warszawa 2002, s. 25-32.

${ }^{15}$ Z. Pierścionek, Współczesne koncepcje konkurencyjności..., s. 17.

${ }^{16}$ Ibidem. 


\section{Nowsze koncepcje kreowania przewagi konkurencyjnej przedsiębiorstwa}

Nowsze koncepcje konkurencyjności przedsiębiorstwa uwzględniają wyzwania wynikające z gwałtownych zmian w jego otoczeniu. Wyróżnikami współczesnych koncepcji konkurencyjności są w pierwszej kolejności innowacje, przedsiębiorczość i powiązania sieciowe firm w sektorze. Zakłada się w nich m.in., że przewagę konkurencyjną można tworzyć poprzez np. ${ }^{17}$ :

- ciągłe opracowywanie i wdrażanie innowacji produktowych, technologicznych, w zakresie organizacji i zarządzania, obsługi rynku itp., kreowanie nowych potrzeb klientów i nowych rynków, nieustanne poszukiwanie nowych okazji biznesowych, wchodzenie na nowe obszary działania (tzw. przedsiębiorcza koncepcja konkurencyjności) ${ }^{18}$;

- ciągłą restrukturyzację rozumianą głównie w kategoriach redukcji kosztów (w sferze zatrudnienia i sferze produktowo-rynkowej) czy szerzej reengineeringu podstawowych procesów biznesowych (tzw. restrukturyzacyjna koncepcja przedsiębiorczości).

Proces budowania przewagi konkurencyjnej na pewno wymaga wprowadzania zmian i innowacji w przedsiębiorstwie. Trzeba jednak podkreślić, że decyzje o jej tworzeniu na bazie innowacji muszą być szczególnie przemyślane. $\mathrm{Z}$ jednej strony innowacje mają duży potencjał rozwojowy i mogą stać się źródłem trwałej przewagi konkurencyjnej, z drugiej zaś znacząco zwiększają ryzyko techniczne i ryzyko rynkowe. Niektórzy autorzy zalecają, aby do przełomowych innowacji przystępować nie w sytuacji, gdy są one obiecujące dla przedsiębiorstwa, lecz tylko wtedy kiedy mają zasadnicze znaczenie dla uczestników rynku ${ }^{19}$. Jeżeli narzuci się je klientom, którzy nie są do tego przygotowani, może minąć wiele lat, zanim zostaną zaakceptowane ${ }^{20}$.

Wyjątkowy i bardzo interesujący wydaje się również sposób tworzenia przewagi konkurencyjnej za pomocą reengineeringu procesów biznesowych. Sprzyjają temu przede wszystkim podstawowe właściwości tej metody zarządzania, takie jak zorientowanie na potrzeby klientów, podejście procesowe,

${ }^{17}$ M.E. Porter, Porter o konkurencji, PWE, Warszawa 2001, s. 47.

${ }^{18}$ Więcej o przedsiębiorczości jako szczególnym źródle przewagi konkurencyjnej, zapewniającym wysoką rentowność i prowadzącym do rywalizacji rynkowej najmniej wyniszczającej dla jej uczestników, a także o przedsiębiorczych strategiach konkurencji zob. np. Z. Pierścionek, Strategie konkurencji i rozwoju przedsiębiorstwa, Wydawnictwo Naukowe PWN, Warszawa 2006, s. 209-224.

${ }^{19}$ M. Treacy, Innovation as a last resort, „Harvard Business Review” 2004, vol. 82, no. 7-8, s. $29-30$.

${ }^{20}$ Aczkolwiek warto również pamiętać, że przełomowe innowacje są raczej rzadkie i mają tak pożądane cechy, jak unikatowość i ograniczoną substytucyjność, a zatem mogą być źródłem trudnej do powielenia przewagi konkurencyjnej. Innowacje usprawniające o charakterze ulepszeń zazwyczaj tylko pomagają w utrzymywaniu już osiągniętej pozycji rynkowej. 
promowanie wydajnych rozwiązań informatycznych, skoncentrowanie się na działaniach tworzących wartość dodaną dla klienta, a także zwiększenie efektywności zasobów oraz działalności podstawowej i wspomagającej ${ }^{21}$.

$\mathrm{Z}$ kolei zgodnie z relacyjną teorią konkurencji, przedsiębiorstwa w swoich zachowaniach dążą do ograniczenia konkurencji przez zawieranie strategicznych sojuszy i długofalowych porozumień. Istnienie sieci powiązań między przedsiębiorstwami danego sektora (powiązań o charakterze zarówno kontraktowym, jak i informacyjnym) prowadzi do intensyfikacji konkurencji i podwyższenia barier wejścia oraz implikuje pozycję danej firmy i wpływa na możliwości osiągania przewagi konkurencyjnej ${ }^{22}$. Sieci partnerskich powiązań wspierają bowiem podstawowe procesy operacyjne danego przedsiębiorstwa, takie jak zarządzanie łańcuchem dostaw, wprowadzanie innowacji czy budowanie relacji z klientami, dzięki czemu może ono znacznie przyspieszyć kreowanie przewagi konkurencyjnej. W kontekście powiązań sieciowych wskazuje się zazwyczaj cztery źródła przewagi konkurencyjnej ${ }^{23}$ :

- inwestowanie w specyficzne zasoby, umożliwiające tworzenie i rozwijanie wzajemnych relacji;

- wymienianie się wiedzą i procesy wspólnego uczenia się;

- łączenie zasobów/umiejętności pozwalających na tworzenie unikatowych produktów/usług lub technologii;

- zmniejszenie kosztów transakcyjnych będące skutkiem zastosowania bardziej efektywnych mechanizmów zarządzania.

W odróżnieniu od tradycyjnego podejścia do konkurencyjności przedsiębiorstw, w nowszych ujęciach teoretycznych, na przykład w teorii hiperkonkurencji, przyjmuje się, że o sukcesie firmy decydują działania polegające na atakowaniu konkurentów, dynamizowaniu rynku, wychodzeniu z niego w odpowiednim momencie i przenoszeniu się na nowy rynek oraz umiejętność efektywnego tworzenia sekwencji krótkookresowych przewag konkurencyjnych ${ }^{24}$. W tej sytuacji trwała przewaga konkurencyjna wynika wyłącznie ze zdolności do kreowania krótkookresowej przewagi konkurencyjnej.

${ }^{21}$ Więcej o przewadze konkurencyjnej przedsiębiorstwa budowanej za pomocą reengineeringu zob. G. Krzos, Business Process Reengineering a pozycja konkurencyjna przedsiębiorstwa, Wydawnictwo AE we Wrocławiu, Wrocław 2006, s. 89-103.

${ }^{22}$ W. Czakon, Ku systemowej teorii przewagi konkurencyjnej przedsiębiorstwa, „Przegląd Organizacji” 2005 , nr 5, s. 8. Sieci partnerskich powiązań wspierają podstawowe procesy operacyjne danego przedsiębiorstwa, takie jak zarządzanie łańcuchem dostaw, wprowadzanie innowacji czy budowanie relacji z klientami, dzięki czemu może ono przyspieszyć tworzenie przewagi konkurencyjnej.

${ }^{23}$ G. Śmigielska, Kreowanie przewagi konkurencyjnej w handlu detalicznym, Wydawnictwo AE w Krakowie, Kraków 2007, s. 53.

${ }^{24}$ R.A. D'Aveni, Hypercompetitive Rivalries: Competing in Highly Dynamic Environments, Free Press, New York 1995, s. 220, [za:] Z. Pierścionek, Współczesne koncepcje konkurencyjności..., s. 18. 
Spośród współczesnych uniwersalnych koncepcji konkurencyjności przedsiębiorstw na szczególną uwagę zasługują nowsze rodzaje podejścia zasobowego, gdyż odnoszą się one do pierwotnych źródeł przewagi konkurencyjnej firmy, będących zarazem strukturalną podstawą kształtowania konkurencyjności w dhuższym okresie. Te bazowe (strukturalne) źródła przewagi, umożliwiające zbudowanie dynamicznego, efektywnego, wrażliwego na potrzeby klientów przedsiębiorstwa, są określane m.in. w kategoriach zdolności firmy, rdzenia umiejętności (kluczowych kompetencji) bądź wyróżniających firmę zdolności i dostosowywania do nich domeny działania, a także wiedzy i umiejętności jej wykorzystania, osiąganych poprzez odpowiednie zarządzanie nią w przedsiębiorstwie.

Bazowe źródła przewagi, stanowiąc mocne strony przedsiębiorstwa, determinują kierunki jego rozwoju, wybierane są bowiem nowe produkty/usługi oraz rynki, na których mogą one zostać najlepiej wykorzystane ${ }^{25}$. Jednocześnie uwzględniają szczególną rolę wiedzy i procesu organizacyjnego uczenia się w wyborze strategii przedsiębiorstwa, a tym samym w budowaniu i podtrzymywaniu jego przewagi konkurencyjnej dzięki efektywniejszemu wykorzystywaniu zasobów firmy ${ }^{26}$. Coraz częściej są formułowane nawet opinie, że trwałość przewagi konkurencyjnej jest uwarunkowana posiadaniem przez przedsiębiorstwo wiedzy organizacyjnej niezbędnej do podejmowania działań adekwatnych do zmieniających się warunków otoczenia. Zakłada się przy tym, że pozostałe źródła przewagi, chociaż w zasadzie różniące się trwałością i znaczeniem, są o tyle ważne, o ile wspomagają proces zarządzania wiedzą i na tyle znaczące $\mathrm{w}$ procesie kreowania przewagi, na ile obrano właściwą strategię ich wykorzystania ${ }^{27}$.

Również na rynkach globalnych wewnętrzne zasoby i zdolności przedsiębiorstwa mają znacznie większe znaczenie dla kształtowania jego trwałej przewagi konkurencyjnej niż źródła egzogeniczne, takie jak na przykład mniejszy koszt siły roboczej czy infrastruktura, ponieważ występują większe trudności $\mathrm{w}$ ich kopiowaniu ${ }^{28}$. Z kolei G.S. Yip uważa, że na etapie wdrażania zintegrowanego zarządzania ogólnoświatowymi (w tym także sieciowymi) zasobami

${ }^{25}$ E. Sitek, Strategia rozwoju w ujęciu zasobowej teorii firmy, „Ekonomista” 1997, nr 5-6, s. 764-765; S. Sysko-Romańczuk, Koncepcja zasobowa firmy wedlug Edith T. Penrose w nurcie rozważań nad wzrostem firmy, „Przegląd Organizacji” 2007, nr 7-8, s. 22.

${ }^{26}$ Szerzej na temat organizacyjnego uczenia się, wiedzy i zarządzania wiedzą jako zasadniczych źródłach konkurencyjności przedsiębiorstwa zob. m.in. w: Z. Pierścionek, Wspótczesne koncepcje konkurencyjności..., s. 37-46 lub idem, Strategie konkurencji..., s. 252-257; J. Rokita, Zarzadzanie strategiczne. Tworzenie i utrzymywanie przewagi konkurencyjnej, PWE, Warszawa 2005, s. 105-136; A. Sudolska, Zasoby wiedzy jako strategiczny czynnik międzynarodowej konkurencyjności przedsiębiorstwa, [w:] M.J. Stankiewicz (red.), Zarządzanie wiedza jako kluczowy czynnik..., s. 62-114.

${ }^{27}$ G. Śmigielska, Kreowanie przewagi konkurencyjnej..., s. 57.

${ }^{28}$ Zob. szerzej J. Fahy, A resource-based analysis of sustainable competitive advantage in a global environment, „International Business Review” 2002, vol. 11, no. 1, s. 57-78; idem, The Role of Resources in Global Competition, Routledge, London 2001. 
firmy i jej przewagą konkurencyjną równie ważne są zarówno czynniki określające pozycję i zasoby przedsiębiorstwa, jak i czynniki globalizacji sektora, dotyczące zwłaszcza rynków, kosztów czy zachowania rządów ${ }^{29}$. Zintegrowanie działań konkurencyjnych na poziomie ogólnoświatowym wymaga posiadania kluczowych kompetencji, a przede wszystkim uczenia się i umiejętności wykorzystywania wiedzy w praktyce. Kluczowe kompetencje przedsiębiorstw funkcjonujących w skali globalnej, oparte na wiedzy, powinny umożliwiać elastyczne reagowanie na zmiany zachodzące w szeroko rozumianym otoczeniu i skuteczne dostosowywanie do trendów technologicznych czy konsumpcyjnych na najważniejszych rynkach.

\section{3. Źródła przewagi konkurencyjnej przedsiębiorstwa w świetle teorii przewagi zasobowej S.D. Hunta i R.M. Morgana}

W świetle dotychczasowych rozważań zasadne wydaje się wyeksponowanie poglądu, że zasadniczymi źródłami przewagi konkurencyjnej są obecnie wyróżniające zasoby i umiejętności, w tym zwłaszcza ogół relacji wewnątrz przedsiębiorstwa $\mathrm{i}$ tych łączących je $\mathrm{z}$ otoczeniem, które łącznie stanowią o jego zdolności do zaspokajania potrzeb klientów w wyższym stopniu niż konkurenci, umożliwiając $\mathrm{w}$ ten sposób osiągnięcie większej wartości dodanej oraz mistrzostwo działania ${ }^{30}$.

Zasoby są przedstawiane m.in. w kategoriach czynników wejściowych (input factors) - widzialnych (materialnych) i niewidzialnych (niematerialnych) - kontrolowanych i używanych przez przedsiębiorstwo w celu rozwijania i wdrażania swoich strategii ${ }^{31}$. Każda firma dysponuje unikatową konfiguracją zasobów, które charakteryzują się heterogenicznością i ograniczoną mobilnością. Z kolei umiejętności przedsiębiorstwa odnoszą się do czynników umożliwiających mu prowadzenie działalności skuteczniej niż konkurentom; mogą być

${ }^{29}$ G.S. Yip, Strategia globalna, PWE, Warszawa 2004, s. 36.

${ }^{30}$ Por. H. Ma, Creation and preemption for competitive advantage, „Management Decision” 1999, vol. 37, no. 3, s. 261. Niektórzy autorzy traktują relacje jako odrębne źródło przewagi konkurencyjnej, ponieważ, wychodząc niejako na zewnątrz przedsiębiorstwa, nie są one w pełni od niego zależne, ani też nie są w pełni przez nie kontrolowane. Zob. M. Małkowska, Metody kwantyfikacji przewagi..., s. 73. Warto również zauważyć, że wielu badaczy w ogóle nie rozróżnia pojęć zasobów i umiejętności, posługując się w odniesieniu do nich wyłącznie określeniami „zasoby” lub „zasoby produkcyjne”. Por. np. E. Penrose, The Theory of the Growth of the Firm, Blackwell, Oxford 1959, s. 30.

${ }^{31}$ Por. Ch. Oliver, Sustainable competitive advantage: combining institutional and resourcebased views, „Strategic Management Journal” 1997, vol. 18, no. 9, s. 700. Wyczerpującą charakterystykę zasobowych źródeł przewagi konkurencyjnej można znaleźć np. w: R. Krupski (red.), Rozwój szkoły zasobowej w zarządzaniu strategicznym, „Prace Naukowe Wałbrzyskiej Wyższej Szkoły Zarządzania i Przedsiębiorczości” 2011. 
one utożsamiane z pojęciem kluczowych kompetencji, wyróżniających zdolności czy po prostu wiedzy ${ }^{32}$. Tak zwane zasoby relacyjne dotyczą natomiast czynników umożliwiających firmie uprzywilejowany dostęp do rynku, a ich istota tkwi $\mathrm{w}$ wielorakich powiązaniach przedsiębiorstwa $\mathrm{z}$ innymi podmiotami w otoczeniu oraz w stosunkach panujących wewnątrz przedsiębiorstwa. Należy podkreślić, że zasoby i umiejętności, aby stanowić strukturalną podstawę budowania przewagi konkurencyjnej, muszą spełniać określone warunki ${ }^{33}$.

W tym kontekście warto odwołać się do kompleksowej, alternatywnej teorii konkurencji ${ }^{34}$, nazywanej teorią przewagi komparatywnej (comparative advantage theory) lub teorią przewagi zasobowej (resource-advantage theory), którą w połowie lat 90. XX wieku zaprezentowali S.D. Hunt i R.M. Morgan ${ }^{35}$.

Autorzy teorii przewagi komparatywnej nawiązują bezpośrednio do dokonań teorii zasobowej przedsiębiorstwa (resource-based view of the firm), studiów nad przewagą konkurencyjną z zakresu marketingu i ekonomii organizacji przemysłowej (industrial organization economics), teorii racjonalności ekonomicznej opracowanej przez szkołę austriacką oraz teorii przewagi wynikającej z wyróżniania się na rynku. Przyjmują oni, że istotą konkurowania jest ciągła walka między przedsiębiorstwami o uzyskanie komparatywnej przewagi w zakresie zasobów (heterogenicznych, o ograniczonej mobilności), która z kolei prowadzi do pozycji rynkowej zapewniającej przewagę konkurencyjną w segmencie lub segmentach rynku, a tym samym wyróżniające wyniki ekonomiczne (uzyskanie większych przychodów finansowych) ${ }^{36}$. W sytuacji zdobycia przez przedsiębiorstwo przewagi konkurencyjnej (dzięki osiągniętej przewadze komparatywnej) i zajęcia lepszej pozycji finansowej konkurenci próbują zneu-

${ }^{32}$ Zob. E. Stańczyk-Hugiet, Budowanie trwatej przewagi konkurencyjnej opartej na wiedzy, [w:] J. Jeżak (red.), Rozwój teorii i praktyki zarządzania strategicznego. Doświadczenia krajowe i międzynarodowe. T. 2, Polsko-Amerykańskie Centrum Zarządzania, Łódź 2003, s. 379-386.

${ }^{33} \mathrm{Na}$ przykład zgodnie z modelem VRIO (valuable, rare, inimitable, well organized resources) powinny być one cenne, rzadkie, trudne do imitacji i substytucji oraz dobrze wykorzystane i/lub zorganizowane. Zob. J. Rokita, Zarzadzanie strategiczne..., s. 154-157.

${ }^{34} \mathrm{~W}$ stosunku do neoklasycznej teorii doskonałej konkurencji zakładającej m.in. homogeniczność popytu w ramach sektora, doskonały i darmowy dostęp konsumentów i przedsiębiorstw do informacji, maksymalizację zysku jako cel przedsiębiorstwa, homogeniczność i doskonałą mobilność zasobów, postępowanie i wyniki firmy determinowane w całości przez otoczenie oraz dopasowanie ilościowe w ramach walki konkurencyjnej.

${ }^{35}$ S.D. Hunt, R.M. Morgan, The comparative advantage theory of competition, ,Journal of Marketing" 1995, vol. 59, no. 2, s. 1-15; idem, the resource-advantage theory of competition: Dynamics, path dependencies and evolutionary dimensions, ibidem, 1996, vol. 60, no. 4, s. 107114; idem, Resource-advantage theory: A snake swallowing its tail or a general theory of competition, ibidem, 1997, vol. 61, no. 3, s. 74-82.

${ }^{36}$ S.D. Hunt, A General Theory of Competition. Resources, Competence, Productivity, Economic Growth, Sage Publications Thousand Oaks, London-New Delhi 2000, s. 135. 
tralizować i/lub zrównoważyć przewagi górującej nad nimi firmy poprzez przejęcia, imitację, substytucję lub przełomowe innowacje.

W teorii konkurencji opartej na przewadze zasobowej uwzględnia się fakt wytrącania przez nią rynku z równowagi (stan dynamicznej nierównowagi jest uważany za pożądany i naturalny), a także zakłada się, że innowacje, uczenie się i zdobywanie wiedzy organizacyjnej mają endogeniczny charakter ${ }^{37}$. Teoria ta jest zorientowana procesowo - jej autorzy traktują przewagę konkurencyjną w kategoriach wielofazowego procesu, na początku którego znajdują się zasoby przedsiębiorstwa, przekształcane pod wpływem różnorodnych czynników w przewagę komparatywną (zasobową). Przewaga zasobowa może prowadzić do uzyskania przewagi pozycyjnej, czyli pozycji rynkowej charakteryzującej się przewagami bezwzględnymi i gwarantującej najlepsze wyniki finansowe. Odpowiednio zagospodarowane wyniki działalności przedsiębiorstwa (w postaci inwestycji) służą do podtrzymania, wzmocnienia i rozwijania nowych źródeł przewagi konkurencyjnej. Powyższą koncepcję w wersji rozwiniętej ${ }^{38}$ przedstawiono graficznie na rysunku 1.

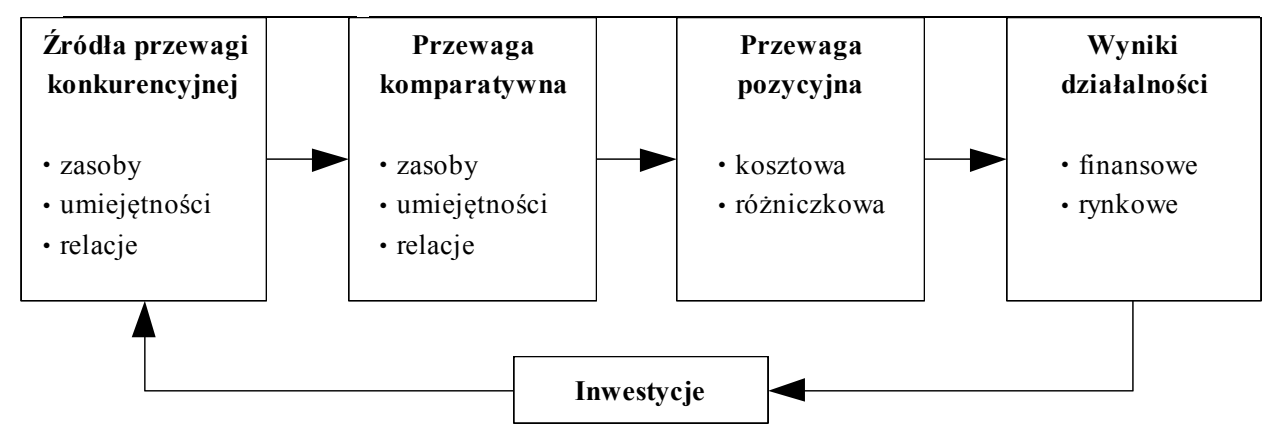

Rysunek 1. Propozycja rozwiniętego ujęcia przewagi konkurencyjnej (z wykorzystaniem teorii przewagi komparatywnej)

Źródło: S.D. Hunt, R.M. Morgan, The comparative advantage theory of competition, ,Journal of Marketing" 1995, vol. 59, no. 2, s. 9; G.S. Day, R. Wensley, Assessing advantage: A framework for diagnosing competitive superiority, ibidem, 1988, vol. 52, s. 3, [za:] M. Małkowska, Metody kwantyfikacji przewagi konkurencyjnej przedsiębiorstwa, [w:] E. Urbanowska-Sojkin, P. Banaszyk (red.), Wspótczesne metody zarządzania strategicznego przedsiębiorstwem, Wydawnictwo AE w Poznaniu, Poznań 2004, s. 72.

${ }^{37}$ Ibidem.

${ }^{38}$ Propozycja rozwiniętego ujęcia przewagi konkurencyjnej nawiązuje zarówno do teorii przewagi komparatywnej, jak i wniosków wynikających z podejścia pozycyjnego i zasobowego. Stanowi ona próbę integracji różnych koncepcji tej przewagi, wskazując jednocześnie, że nie powinno się ich traktować w sposób alternatywny (wariantowy). Akcentują one bowiem różne aspekty przewagi konkurencyjnej przedsiębiorstwa, wzajemnie się uzupełniając. 
Mechanizm osiągania przewagi konkurencyjnej z uwzględnieniem następujących po sobie działań przedsiębiorstwa przedstawił szczegółowo G.S. Day ${ }^{39}$. Punktem wyjścia uczynił on źródła przewagi konkurencyjnej, mające swoje odzwierciedlenie w większej liczbie lepszych jakościowo oraz odpowiednio skonfigurowanych zasobów i umiejętności. W sytuacji pojawienia się w sektorze tzw. kluczowych czynników sukcesu te zasoby i umiejętności służą do tworzenia konkretnej przewagi konkurencyjnej, wyrażającej się w oferowaniu większej wartości dla klienta. Zdobyta przewaga konkurencyjna (w warunkach występowania barier imitacyjnych) oraz dynamiczne zmiany w otoczeniu wpływają na wyniki działalności przedsiębiorstwa, np. zyski, udział w rynku, satysfakcję i lojalność klientów. Z kolei uzyskiwane wyniki oraz nie zawsze przyjazne zmiany $\mathrm{w}$ otoczeniu określają zakres przedsięwzięć inwestycyjnych nakierowanych na wzmacnianie dotychczasowych rodzajów przewagi konkurencyjnej oraz na kreowanie nowych tak, aby były one zdolne do podtrzymywania pozycji konkurencyjnej przedsiębiorstwa.

Proces inwestowania $\mathrm{w}$ odnowienie posiadanych źródeł przewagi konkurencyjnej może odbywać się na wielu płaszczyznach ${ }^{40}$. Im więcej płaszczyzn i im są one trudniejsze do osiągnięcia przez konkurentów, tym korzystniej dla przedsiębiorstwa. Do podstawowych należą ${ }^{41}$ :

- zdobywane nowych obszarów przywództwa strategicznego;

- zwiększanie posiadanych możliwości kreowania przewagi poprzez ciągłe rozwijanie lub radykalne rekonfigurowanie aktualnie wykorzystywanych zasobów, procesów biznesowych itp.;

${ }^{39}$ Zob. szerzej G.S. Day, Maintaining the competitive edge: Creating and sustaining advantages in dynamic competitive environments, [w:] G.S. Day, D.J. Reibstein, R.E. Gunther (eds), Wharton on Dynamic Competitive Strategy, Wiley, Hoboken, NJ 1997, s. 48-75.

${ }^{40}$ A. Adamik, Tymczasowość przewagi konkurencyjnej, „Ekonomika i Organizacja Przedsiębiorstwa" 1999, nr 9, s. 16.

${ }^{41} \mathrm{~W}$ literaturze można znaleźć inne, nie mniej interesujące sposoby podejścia do tego problemu. Na przykład K.P. Coyne proponuje podejmowanie inwestycji w czterech obszarach (możliwościach), skutecznie różnicujących firmę na rynku i będących w stanie zapewnić trwałość osiągniętej przewagi konkurencyjnej. Są to: możliwości regulacyjno-prawne wynikające z posiadanych przez przedsiębiorstwo prawnie uznanych atrybutów, jak kontrakty, tajemnice handlowe, prawa do różnego typu wartości niematerialnych itp.; możliwości pozycyjne będące z reguły konsekwencją działań i decyzji podjętych w przedsiębiorstwie w przeszłości, dotyczące reputacji czy produktywnej konfiguracji zasobów; możliwości funkcjonalne nawiązujące do zdolności do wykonywania określonych operacji, opartych na wiedzy, umiejętnościach i doświadczeniach zarówno pracowników firmy, jak i innych grup mających wpływ na kształtowanie się łańcucha wartości (dostawców, maklerów giełdowych, agencji reklamowych itp.); możliwości kulturowe zawierające zwyczaje, postawy, poglądy, przekonania, wierzenia i wartości, które odnoszą się nie tylko do pojedynczych pracowników firmy, ale przenikają całe grupy pracownicze danego przedsiębiorstwa. Zob. szerzej A. Adamik, Tymczasowość przewagi..., s. 14-15. 
- przejęcie zasobów, które zagrażają obecnej pozycji konkurencyjnej przedsiębiorstwa;

- inwestowanie w poszerzanie posiadanych zasobów o nowe konkurencyjne aktywa.

Zgodnie z założeniami teorii przewagi zasobowej S.D. Hunta i R.M. Morgana, konkurenci podejmują próby neutralizacji i/lub zrównoważenia przewagi konkurencyjnej danego przedsiębiorstwa poprzez przejęcia, imitacje, substytucje lub przełomowe innowacje. W związku z tym źródła przewagi konkurencyjnej można podzielić na zorientowane na budowanie tej przewagi (podejście aktywne) i zorientowane na jej utrzymywanie (podejście pasywne) ${ }^{42}$. W podejściu aktywnym zakłada się wzmocnienie zdolności przedsiębiorstwa do tworzenia wartości w porównaniu z jego konkurentami, co oznacza rozwijanie już posiadanych zasobów, umiejętności i relacji oraz poszukiwanie nowych, stanowiących potencjalne źródła przyszłej przewagi lub umożliwiających zmianę reguł gry na rynku. W podejściu pasywnym chodzi natomiast o zneutralizowanie lub ograniczanie możliwości budowania przewagi konkurencyjnej przez firmy rywalizujące z danym przedsiębiorstwem.

Tabela 1. Źródła przewagi konkurencyjnej zorientowane na jej budowanie oraz utrzymywanie

\begin{tabular}{|l|l|l|}
\hline $\begin{array}{l}\text { Źródła przewagi } \\
\text { konkurencyjnej }\end{array}$ & \multicolumn{1}{|c|}{$\begin{array}{c}\text { Budowanie przewagi } \\
\text { konkurencyjnej (podejście aktywne) }\end{array}$} & $\begin{array}{c}\text { Utrzymywanie przewagi } \\
\text { konkurencyjnej (podejście pasywne) }\end{array}$ \\
\hline Zasoby & $\begin{array}{l}\text { Aktywne pozyskiwanie i groma- } \\
\text { dzenie cennych zasobów, zwięk- } \\
\text { szające wartość przedsiębiorstwa }\end{array}$ & $\begin{array}{l}\text { Blokowanie dostępu konkurentów do } \\
\text { cennych zasobów i ograniczanie swo- } \\
\text { body manewru strategicznego rywali }\end{array}$ \\
\hline Umiejętności & $\begin{array}{l}\text { Doskonalenie procesów organizacyj- } \\
\text { nego uczenia się i wdrażanie najlep- } \\
\text { szych praktyk zarządzania wiedzą }\end{array}$ & $\begin{array}{l}\text { Zapobieganie naśladownictwu i ogra- } \\
\text { niczanie możliwości organizacyjnego } \\
\text { uczenia się w konkurencyjnych } \\
\text { firmach w celu tworzenia im barier } \\
\text { rozwoju }\end{array}$ \\
\hline Relacje & $\begin{array}{l}\text { Tworzenie możliwości dostępu do } \\
\text { zasobów i umiejętności poprzez } \\
\text { kształtowanie sieci wielorakich po- } \\
\text { wiązań z interesariuszami przedsię- } \\
\text { biorstwa }\end{array}$ & $\begin{array}{l}\text { Utrudnianie lub blokowanie możliwo- } \\
\text { ści budowania sieci powiązań mię- } \\
\text { dzyorganizacyjnych przez konkuren- } \\
\text { tów }\end{array}$ \\
\hline
\end{tabular}

Źródło: opracowanie na podstawie H. Ma, Creation and preemption for competitive advantage, „Management Decision” 1999, vol. 37, no. 3, s. 261.

${ }^{42}$ H. Ma, Creation and preemption..., s. 261-262. Por. też Z. Matyjas, Wzorce konkurowania przedsiębiorstw w sektorach - podejście dynamiczne, Wydawnictwo UŁ, Łódź 2013, s. 47-52. 
W praktyce $\mathrm{w}$ celu uzyskania względnie trwałego, wysokiego poziomu efektywności przedsiębiorstwo musi tworzyć i odnawiać konfigurację różnych rodzajów przewagi nad konkurentami, dlatego najlepszym rozwiązaniem jest kompleksowe podejście do budowania strategii osiągania przewagi konkurencyjnej. G. Hamel i C.K. Prahalad źródeł możliwej do odnawiania przewagi konkurencyjnej upatrują w zarządzaniu opartym na „kodzie genetycznym” przedsiębiorstwa, nastawionym na ciągłe poszukiwanie wyprzedzających czas strategii rozwoju. Źródłem tym nie mogą już być pojedyncze mocne strony przedsiębiorstwa, ale jego wyróżniające się lub kluczowe kompetencje, stanowiące pewną całość różnorodnych umiejętności w obszarze technologii, produkcji i zarządzania ${ }^{43}$. Zdaniem tych autorów, trudno jest na współczesnym rynku utrzymać przewagę konkurencyjną budowaną wyłącznie na jednym źródle (kosztowym, jakościowym czy czasowym).

\section{Zakończenie}

Sposoby alokacji zasobów i umiejętność ich wykorzystania przez przedsiębiorstwo przesądzają o jego zdolnościach do skutecznego konkurowania dzisiaj oraz do budowania przewagi konkurencyjnej w przyszłości ${ }^{44}$. Skuteczna rywalizacja rynkowa jest niezbędnym warunkiem przetrwania i rozwoju współczesnych firm, dlatego dążą one do stworzenia i podtrzymywania przewagi konkurencyjnej. Jak wspomniano, ze względu na dużą dynamikę i charakter zmian zarówno w przedsiębiorstwie, jak i w jego otoczeniu przewaga konkurencyjna nie jest jednak osiągana raz na zawsze. Ponadto nie każda przewaga konkurencyjna i nie każdy jej zakres zapewniają osiąganie lepszych wyników i sukces rynkowy. Dlatego niezwykle istotne staje się poszukiwanie możliwości odnawiania zdobytej przewagi konkurencyjnej w dłuższym okresie oraz odpowiedzi na pytanie o jej względną trwałość rozumianą jako sekwencja krótkich okresów, w których przedsiębiorstwo dzięki uzyskanej przewadze może osiągać wyniki lepsze od konkurentów.

Stopień tak pojmowanej trwałości przewagi konkurencyjnej jest określany wewnątrz przedsiębiorstwa przez takie czynniki, $\mathrm{jak}^{45}$ :

- charakter źródeł tej przewagi;

- liczba odrębnych źródeł i ich konfiguracja;

${ }^{43}$ G. Hamel, C.K. Prahalad, Przewaga konkurencyjna jutra. Strategie przejmowania kontroli nad branża i tworzenia rynków przyszłości, Business Press, Warszawa 1999, s. 231-246 (wydanie oryginalne: Competing for the Future, Harvard Business School Press, Boston 1994).

${ }^{44}$ Ibidem, s. 76.

${ }^{45}$ W.J. Otta, Strategia przedsiębiorstwa na rynkach zagranicznych, [w:] T. Gołębiowski (red.), Przedsiębiorstwo na rynku międzynarodowym. Analiza strategiczna, PWN, Warszawa 1994, s. 71. 
- stałe doskonalenie i podnoszenie poziomu przewagi;

poza tym wpływ na niego mają warunki panujące w otoczeniu przedsiębiorstwa ${ }^{46}$ :

- zmiana gustów i preferencji obecnych i potencjalnych konsumentów;

- zdolność konkurentów do naśladowania i/lub prześcigania danej firmy w tworzeniu przewag konkurencyjnych.

\section{Literatura}

Adamik A., Tymczasowość przewagi konkurencyjnej, „Ekonomika i Organizacja Przedsiębiorstwa" 1999, nr 9.

Brzozowska E., Przewaga konkurencyjna elementem konkurencyjności przedsiębiorstw, [w:] J. Szabłowski (red.), Strategie konkurencji przedsiębiorstw - wybrane zagadnienia, Wydawnictwo Wyższej Szkoły Finansów i Zarządzania w Białymstoku, Białystok 2004.

Cyrson E., Nowy paradygmat strategii konkurencji, [w:] E. Skawińska (red.), Konkurencyjność przedsiębiorstw - nowe podejście, Wydawnictwo Naukowe PWN, Warszawa-Poznań 2002.

Czakon W., Ku systemowej teorii przewagi konkurencyjnej przedsiębiorstwa, „Przegląd Organizacji” 2005, nr 5.

D’Aveni R.A., Hypercompetitive Rivalries: Competing in Highly Dynamic Environments, Free Press, New York 1995.

Day G.S., Maintaining the competitive edge: Creating and sustaining advantages in dynamic competitive environments, [w:] G.S. Day, D.J. Reibstein, R.E. Gunther (eds), Wharton on Dynamic Competitive Strategy, Wiley, Hoboken, NJ 1997.

Day G.S., Reibstein D.J., Gunther R.E. (eds), Wharton on Dynamic Competitive Strategy, Wiley, Hoboken, NJ 1997.

Day G.S., Wensley R., Assessing advantage: A framework for diagnosing competitive superiority, „Journal of Marketing” 1988, vol. 52.

Fahy J., A resource-based analysis of sustainable competitive advantage in a global environment, „International Business Review” 2002, vol. 11, no. 1.

Fahy J., The Role of Resources in Global Competition, Routledge, London 2001.

Faulkner D., Bowman C., Strategie konkurencji, Gebethner i Ska, Warszawa 1996.

Godziszewski B., Zasobowe uwarunkowania strategii przedsiębiorstwa, Wydawnictwo UMK, Torun 2001.

Gołębiowski T. (red.), Przedsiębiorstwo na rynku międzynarodowym. Analiza strategiczna, PWN, Warszawa 1994.

Haffer M., Ogólna charakterystyka wspótczesnej konkurencji międzynarodowej, [w:] M.J. Stankiewicz (red.), Zarządzanie wiedza jako kluczowy czynnik międzynarodowej konkurencyjności przedsiębiorstwa, TNOiK Dom Organizatora, Toruń 2006.

Hamel G., Prahalad C.K., Przewaga konkurencyjna jutra. Strategie przejmowania kontroli nad branża i tworzenia rynków przyszłości, Warszawa: Business Press 1999 (wydanie oryginalne: Competing for the Future, Harvard Business School Press, Boston 1994).

Hunt S.D., A General Theory of Competition. Resources, Competence, Productivity, Economic Growth, Sage Publications Thousand Oaks, London-New Delhi 2000.

${ }^{46}$ B. Godziszewski, Zasobowe uwarunkowania strategii przedsiębiorstwa, Wydawnictwo UMK, Toruń 2001, s. 60 . 
Hunt S.D., Morgan R.M., Resource-advantage theory: A snake swallowing its tail or a general theory of competition, „Journal of Marketing” 1997, vol. 61, no. 3.

Hunt S.D., Morgan R.M., The comparative advantage theory of competition, „Journal of Marketing" 1995 , vol. 59 , no. 2.

Hunt S.D., Morgan R.M., The resource-advantage theory of competition: Dynamics, path dependencies and evolutionary dimensions, „Journal of Marketing” 1996, vol. 60, no. 4.

Jeżak J. (red.), Rozwój teorii i praktyki zarządzania strategicznego. Doświadczenia krajowe i międzynarodowe. T. 2, Polsko-Amerykańskie Centrum Zarządzania, Łódź 2003.

Kotler P., Gestern A., Jak wygrywać w warunkach hiperkonkurencji, „Rzeczpospolita” 2001, nr 74, dodatek: „Moja kariera”.

Krupski R. (red.), Rozwój szkoły zasobowej w zarządzaniu strategicznym, „Prace Naukowe Wałbrzyskiej Wyższej Szkoły Zarządzania i Przedsiębiorczości” 2011.

Krzos G., Business Process Reengineering a pozycja konkurencyjna przedsiębiorstwa, Wydawnictwo AE we Wrocławiu, Wrocław 2006.

Ma H., Creation and preemption for competitive advantage, „Management Decision” 1999, vol. 37 , no. 3 .

Macias J., Nowe koncepcje przewagi konkurencyjnej współczesnych przedsiębiorstw, „Przegląd Organizacji” 2008, nr 9.

Makadok R., Can first-mover and early-mover advantages be sustained in an industry with low barriers to entry/imitation, „Strategic Management Journal” 1998, vol. 19, no. 7.

Małkowska M., Metody kwantyfikacji przewagi konkurencyjnej przedsiębiorstwa, [w:] E. Urbanowska-Sojkin, P. Banaszyk (red.), Współczesne metody zarządzania strategicznego przedsiębiorstwem, Wydawnictwo AE w Poznaniu, Poznań 2004.

Matyjas Z., Wzorce konkurowania przedsiębiorstw w sektorach-podejście dynamiczne, Wydawnictwo UŁ, Łódź 2013.

McNamara G., Vaaler P.M., Devers C., Same as it ever was: the search for evidence of increasing hypercompetition, „Strategic Management Journal” 2003, vol. 24, no. 3.

Oliver Ch., Sustainable competitive advantage: combining institutional and resource-based views, „Strategic Management Journal” 1997, vol. 18, no. 9.

Otta W.J., Strategia przedsiębiorstwa na rynkach zagranicznych, [w:] T. Gołębiowski (red.), Przedsiębiorstwo na rynku międzynarodowym. Analiza strategiczna, PWN, Warszawa 1994.

Penrose E., The Theory of the Growth of the Firm, Blackwell, Oxford 1959.

Pierścionek Z., Jurek-Stępień S. (red.), Czynniki sukcesu polskich przedsiębiorstw na rynkach Unii Europejskiej, Szkoła Główna Handlowa w Warszawie - Oficyna Wydawnicza, Warszawa 2006.

Pierścionek Z., Klasyfikacja źródet przewagi konkurencyjnej, [w:] K. Poznańska, A. Sosnowska (red.), Źródła przewagi konkurencyjnej przedsiębiorstw, Szkoła Główna Handlowa, Warszawa 2002.

Pierścionek Z., Strategie konkurencji i rozwoju przedsiębiorstwa, Wydawnictwo Naukowe PWN, Warszawa 2006.

Pierścionek Z., Współczesne koncepcje konkurencyjności przedsiębiorstwa, [w:] Z. Pierścionek, S. Jurek-Stępień (red.), Czynniki sukcesu polskich przedsiębiorstw na rynkach Unii Europejskiej, Szkoła Główna Handlowa w Warszawie - Oficyna Wydawnicza, Warszawa 2006.

Polowczyk J., Zarządzanie strategiczne $w$ przedsiębiorstwie $w$ ujęciu behawioralnym, Wydawnictwo UE w Poznaniu, Poznań 2012.

Porter M.E., Przewaga konkurencyjna. Osiaganie i utrzymywanie lepszych wyników, Helion, Gliwice 2006 (wydanie oryginalne: M.E. Porter, Competitive Adventage: Creating and Sustaining Superior Performance, Free Press, New York 1985). 
Poznańska K., Sosnowska A. (red.), Źródła przewagi konkurencyjnej przedsiębiorstw, Szkoła Główna Handlowa, Warszawa 2002.

Rokita J., Zarzadzanie strategiczne. Tworzenie $i$ utrzymywanie przewagi konkurencyjnej, PWE, Warszawa 2005.

Singer A.E., Hypercompetition, Business Press-Thomson Learning, London 2000.

Sitek E., Strategia rozwoju w ujęciu zasobowej teorii firmy, „Ekonomista” 1997, nr 5-6.

Skawińska E. (red.), Konkurencyjność przedsiębiorstw - nowe podejście, Wydawnictwo Naukowe PWN, Warszawa-Poznań 2002.

Stankiewicz M.J. (red.), Zarządzanie wiedza jako kluczowy czynnik międzynarodowej konkurencyjności przedsiębiorstwa, TNOiK Dom Organizatora, Torun 2006.

Stankiewicz M.J., Konkurencyjność przedsiębiorstwa. Budowanie konkurencyjności przedsiębiorstwa w warunkach globalizacji, TNOiK Dom Organizatora, Torun 2002.

Stańczyk-Hugiet E., Budowanie trwatej przewagi konkurencyjnej opartej na wiedzy, [w:] J. Jeżak (red.), Rozwój teorii i praktyki zarządzania strategicznego. Doświadczenia krajowe i międzynarodowe. T. 2, Polsko-Amerykańskie Centrum Zarządzania, Łódź 2003.

Sudolska A., Zasoby wiedzy jako strategiczny czynnik międzynarodowej konkurencyjności przedsiębiorstwa, [w:] Stankiewicz M.J. (red.), Zarządzanie wiedza jako kluczowy czynnik międzynarodowej konkurencyjności przedsiębiorstwa, TNOiK Dom Organizatora, Toruń 2006.

Sysko-Romańczuk S., Koncepcja zasobowa firmy wedtug Edith T. Penrose w nurcie rozważań nad wzrostem firmy, „Przegląd Organizacji” 2007, nr 7-8.

Szabłowski J. (red.), Strategie konkurencji przedsiębiorstw - wybrane zagadnienia, Wydawnictwo Wyższej Szkoły Finansów i Zarządzania w Białymstoku, Białystok 2004.

Śmigielska G., Kreowanie przewagi konkurencyjnej w handlu detalicznym, Wydawnictwo AE w Krakowie, Kraków 2007.

Świtalski W., Innowacje i konkurencyjność, Wydawnictwo UW, Warszawa 2005.

Treacy M., Innovation as a Last Resort, „Harvard Business Review” 2004, vol. 82, no. 7-8.

Urbanowska-Sojkin E., Banaszyk P. (red.), Wspótczesne metody zarządzania strategicznego przedsiębiorstwem, Wydawnictwo AE w Poznaniu, Poznań 2004.

Wiggins R.W., Ruefli T.W., Schumpeter's ghost: Is hypercompetition making the best of times shorter, „Strategic Management Journal” 2005, vol. 26, no. 10.

Yip G.S., Strategia globalna, PWE, Warszawa 2004.

\section{Streszczenie}

Celem niniejszego opracowania jest omówienie na podstawie literatury przedmiotu najważniejszych wątków w dyskusji o źródłach kreowania przewagi konkurencyjnej współczesnego przedsiębiorstwa oraz wskazanie tych źródeł, które przesądzają o jego zdolności do rozwijania zbioru przewag okresowych. Odwołując się do teorii przewagi komparatywnej (comparative advantage theory), zwanej także teorią przewagi zasobowej (resource-advantage theory), sformułowanej przez S.D. Hunta i R.M. Morgana, opisano mechanizm osiągania przewagi konkurencyjnej z uwzględnieniem następujących po sobie działań przedsiębiorstwa. 


\section{Summary \\ THE SOURCES OF THE COMPETITIVE ADVANTAGE IN ENTERPRISE - THE STATE OF ART}

The purpose of the chapter is the presentation of main themes for literature discussion on the sources of creation the competitive advantage in contemporary enterprise and the indication the sources deciding on its possibility to develop the data set of advantages. The mechanism of achieving the competitive advantage in connection with comparative advantage theory (resource-advantage theory) formulated by S.D. Hunt and R.M. Morgan has been described as a result of subsequent enterprise actions. 